\title{
Pemikiran Rakawi Yusuf Dengan Rujukan Khusus Terhadap Novel Melati Sarawak 1932 : Satu Tinjauan Awal
}

\section{oleh}

\author{
Nordi bin Achie
}

\section{PENGENALAN}

Perkembangan fiksyen (novel dan cerpen) Melayu di Tanah Melayu khususnya dan Malaysia umumnya, bermula pada 1925 apabila novel Kelebiban Bersababat diterbitkan oleh Matbaah al-Jamiliah, Muar.' Dalam tempoh 1925-1945, sebanyak 300 buah novel dihasilkan oleh novelis Melayu. Perkembangan novel di Tanah Melayu mencapai kemuncaknya pada 1930-an. Daripada 300 buah novel, kira-kira 173 diterbitkan pada 1930-an. ${ }^{2}$ Perkembangan novel Melayu yang semakin pesat di Tanah Melayu turut mengesani kegiatan penulisan di kalangan golongan terpelajar Melayu di Sarawak. Dalam situasi inilah terbitnya novel Melati Sarawak. Ia dikarang oleh Muhammad Rakawi Yusuf. ${ }^{3}$ Namun, pemikiran Rakawi Yusuf dan Melati Sarawak jarang diberikan perhatian oleh pengkaji tanah air berbanding tokoh sastera sezaman seperti Syed Sheikh AlHadi, Ahmad Rashid Talu, Ishak Haji Muhammad, Harun Aminurashid dan Abdul Rahim Kajai. ${ }^{4}$ Oleh itu, artikel ini bertujuan mengupas intisari pemikiran 
Rakawi Yusuf terhadap kemajuan bangsanya berdasarkan novel Melati Sarawak. Ia dijadikan sebagai teks kajian sejajar dengan kepentingannya sebagai pemancar pemikiran Rakawi Yusuf.'

\section{RAKAWI YUSUF ; NOVELIS DAN NASIONALIS MELAYU}

Rakawi Yusuf dilahirkan sekitar 1890-an di Kampung No. 3, Jalan Muhibbah, Kuching. Beliau mendapat pendidikan awal di Sekolah St. Joseph dan Kolej Kebangsaan Sarawak, Kuching. ${ }^{6}$ Sebelum menjadi pegawai kastam, Rakawi Yusuf pernah berkhidmat sebagai guru. Selain mengajarkan Islam kepada orang Melayu, Rakawi Yusuf juga mengajarkan bahasa Melayu kepada orang Inggeris dan orang Cina.' Beliau turut dikenali sebagai 'Master Rakawi' kerana peranannya sebagai guru silat. Selepas bersara sebagai pegawai kastam, Rakawi Yusuf bersama Johari Anang, Haji Daud Abdul Ghani, Abdul Rahman Kassim dan Awi Anang menerbitkan Fajar Sarawak pada 1 Februari 1930. Fajar Sarawak merupakan akhbar Melayu pertama di Borneo. Selain menjadi tenaga pengasas PASPAM Cawangan Kuching, Rakawi Yusuf turut menganggotainya pada 1936. Beliau dipercayai pernah menghadiri mesyuarat PASPAM di Singapura. Beliau juga mempunyai hubungan rapat dengan pemimpin Kesatuan Melayu Singapura. Rakawi Yusuf pernah melawat Tanah Melayu sekitar akhir 1920-an hingga awal 1930-an. Ini mendedahkannya terhadap perkembangan persuratkhabaran dan perjuangan masyarakat Melayu di Tanah Melayu. Pada 1934-1936, Rakawi Yusuf dilantik sebagai wakil orang Melayu dalam Kuching Sanitary and Municipal Advisory Board. Selepas kegagalan Fajar Sarawak, Rakawi Yusuf masih lagi bergiat aktif dalam bidang penulisan. Sebelum meninggal dunia pada 1936, Rakawi Yusuf menghasilkan novel Melati Sarauvak dan Hikayjat Sarauvak. Keduaduanya diterbitkan oleh Sarawak Printing Company pada awal 1930-an. Melati Sarawak merupakan karyanya yang tidak disadur dari sebarang karya sastera sama ada dari Tanah Melayu atau Indonesia. ${ }^{8}$ Hikayat Sarawak pula adalah Selsilab, tulisan Hugh 1839-1908, tulisan S. Barin A History of Sarawak Under Its Two Rajabs jilid, cetakan jawi.9 Sumbangan dan C. A. Bambflyd. Ia diterbitkan dua ialah penubuhan Persatuan Kean terunggul Rakawi Yusuf terhadap bangsanyz bersama Johari Arang dan Kebangsaan Melayu Sarawak ( PKMS). Rakawi Yusuf Rakawi Yusuf tidak sempat menyahman Kassim merupakan pengasasnya. Tetapi, nnya. PKMS didaftarkan secara 
rasmi pada 10 Oktober 1939. Usaha awal mendaftarkan PKMS pada 1937 menemui kegagalan kerana wujudnya tentangan daripada segelintir golongan
perabangan Melayu. ${ }^{10}$

\section{PEMIKIRAN RAKAWI YUSUF : ASAS DAN LATAR BELAKANGNYA}

Menjelang awal abad ke-20, Brooke berjaya mengukuhkan kuasa dan kedudukannya di Sarawak. Wilayah Sarawak memanjang dari Kuching hingga ke Lawas. Sistem pentadbiran Brooke disusun dengan rapi. Jawatan tertinggi pentadbirannya, dikuasai oleh 'orang putih'. Brooke juga mengamalkan dasar dikotominisasi terhadap anak negeri. Dalam aspek pentadbiran, anak negeri berdarah perabangan diutamakan menjawat jawatan yang lebih tinggi. Sementara, hak anak negeri yang bukan berketurunan perabangan, dipinggirkan. Ekonomi Sarawak juga semakin berkembang terutamanya mulai dekad pertama abad ke20. Tetapi, ia tidak banyak menguntungkan anak negeri. Kekayaan ekonomi negeri dikuasai oleh bangsa asing. Ketika itu, Sarawak juga dibanjiri oleh pendatang Cina. Ekonomi bandaran, khususnya di Kuching dan Sibu dikuasai oleh peniaga Cina. Masyarakat Cina yang bergiat dalam bidang pertanian pula kemaruk dengan tanah. Ini menyebabkan kepentingan tanah anak negeri terancam. Anak negeri bukan sahaja ketinggalan dalam aspek ekonomi, malah pendidikan juga, terutamanya pendidikan tinggi dan di kalangan anak perempuan. Sebelum 1930, Brooke tidak berusaha membiayai pendidikan pelajar aliran Melayu ke seberang laut. Kesemuanya terpaksa ditanggung oleh ibu bapa, jika mereka ingin melanjutkan pendidikan anak-anaknya. Antara akhir 1920-an dan awal 1930-an, pengaruh reformisme Islam di Tanah Melayu dan Indonesia meresap ke Sarawak ( Kuching ). la meresap ke Kuching menerusi faktor pendidikan, perlawatan dan pengedaran persuratkhabaran. Ini membawa dimensi baru terhadap pemikiran golongan terpelajar Melayu. Mereka merupakan golongan berjiwa Islam dan berusaha menyedarkan masyarakatnya daripada pasungan adat dan budaya yang menyekat kemajuan. Mereka menyedarkan masyarakatnya tentang sikap dan kepercayaan yang memundurkan kehidupan. Ini mewujudkan titisan konflik antara golongan reformis dan tradisionalis dalam masyarakat Melayu. Pengukuhan pemerintahan Brooke turut diiringi oleh peresapan pengaruh Barat. Ia juga mempengaruhi corak kehidupan masyarakat Melayu. Umumnya, masyarakat Melayu mudah menerima budaya Barat sewenang-wenangnya. Ini menyebabkan unsur budaya yang bercanggah 
dengan ajaran Islam dan nilai Melayu, turut mempengaruhi cara hidup masyarakat Melayu khususnya di kalangan pemuda-pemudi. Kesemuanya ini mendefinisikan pemikiran Rakawi Yusuf seperti yang terpancar menerusi novel Melati Sarawak. Pada dasarnya, pemikiran Rakawi Yusuf dapat dibahagikan kepada dua aspek: major dan minor. Aspek majornya mengupas pemikiran Rakawi Yusuf terhadap gendang Melayu. Aspek minornya pula menyentuh secara umum masalah dan persoalan masyarakatnya. Ia mencakupi aspek pentadbiran, pendidikan, ekonomi, kepercayaan dan cara hidup 'zaman baru' di kalangan pemuda-pemudi. Ia diolah oleh Rakawi Yusuf dengan menyelitkannya bersama kritikannya terhadap gendang Melayu.

\section{PEMIKIRAN RAKAWI YUSUF TERHADAP GENDANG MELAYU}

Gendang Melayu merupakan permainan tradisional masyarakat Melayu di Sarawak. Ia tidak terdapat di alam Melayu yang lain. Keunikannya menjadi identiti budaya masyarakat Melayu di Sarawak. Namun, asal-usul permainan gendang Melayu masih tidak diketahui dengan jelas. Ia diwarisi secara turuntemurun oleh masyarakat Melayu. Lazimnya, gendang Melayu diadakan di pesta keramaian khususnya majlis perkahwinan. Gendang Melayu merupakan acara kebudayaan dan tidak ada kaitannya dengan majlis keagamaan. Ia diadakan selepas isya' dan ditamatkan menjelang subuh di rumah penganjur.

Permainan gendang Melayu diwakili oleh tukang gendang. Mereka terdiri daripada tiga hingga lima orang perempuan. Mereka mendapat latihan daripada guru gendang yang berpengalaman. Antara alat asas yang digunakan ialah gendang (rebana). Ia diperbuat khas daripada kulit kambing kering. Selain tukang gendang, mereka turut dibantu oleh penggesel biola dan pemain gitar. Rentak biola dan gitar mesti serasi dengan paluan gendang. Pemain biola dan gitar biasanya lelaki. Semasa bergendang, tukang gendang berpantun secara bergilirgilir. Tukang gendang dan anak-anak perempuan diasingkan daripada lelaki. Biasanya, kain palikat digunakan sebagai tabir untuk memisahkan kawasan tukang gendang dan anak-anak perempuan yang menjadi penonton dan peneman tukang gendang. Mereka duduk di belakang tukang gendang. Lelaki pula bertandak nopeng di sebelah tabir. Satu kawasan khas disediakan kepada mereka untuk bertandak. Semasa bertandak nopeng, terdapat satu acara yang dinamakan 'bermukun' iaitu penandak (lelaki) dan tukang gendang (perempuan) berbalas pantun. 
Permainan gendang Melayu, selain bertujuan untuk berhibur, kesempatan ini juga digunakan oleh pemuda mengorat pemudi. Semasa permainan gendang diadakan, pemuda berpakaian Melayu lengkap : berbaju, berseluar, bersampin dan bersongkok Melayu serta berkasut gelap berkilat-kilat. Pemudi pula berhias dan berpakaian cantik sama ada mengenakan baju kebaya atau baju kurung.

Permainan gendang Melayu masih kekal sehingga ke hari ini. Ia tidak pupus ditelan zaman. Tetapi, ia tidak sepopular sebelum Perang Dunia II. Kini, permainan gendang Melayu dipelihara sebagai warisan budaya masyarakat Melayu Sarawak. Usaha mengekalkannya dilakukan oleh Yayasan Budaya Melayu Sarawak. Selain diadakan sempena majlis perkahwinan, gendang Melayu juga dijadikan sebagai pertunjukan kebudayaan di Kampung Budaya, Santubung dan di Persiaran Tebingan Sungai Sarawak, Kuching.

Pada era 1980-an, permainan gendang Melayu mengalami beberapa perubahan. Pemuda yang bertandak nopeng meminum minuman keras. Mereka mabuk dan ini mencetuskan pergaduhan. Pemudi yang menyaksikan gendang Melayu pula, menggunakan kesempatan ini untuk berbulan madu dengan kekasihnya hingga 'ditangkap basah'. Kerosakan akhlak di kalangan pemudapemudi semakin parah. Akibat pergaduhan yang kerap berlaku di kalangan pemuda yang mabuk, permainan gendang Melayu diketatkan dengan kawalan polis. Di sesetengah tempat, khususnya di Kuching, permit polis mesti dipohon sebagai syarat mengadakan permainan gendang Melayu. Terdapat juga anggota rela yang berkawal semasa permainan gendang Melayu dijalankan.

Kegilaan pemuda terhadap permainan gendang Melayu tidak dapat dinafikan. Mereka sanggup berkonvoi dengan sampan, pergi ke kampung yang mengadakan gendang Melayu semata-mata kerana gendang Melayu. Sesetengahnya, pantang mendengar bunyi gendang. Mereka berasa resah gelisah sekiranya tidak pergi bertandak nopeng. Malah, dipercayai tukang gendang mengamalkan 'petua guru' tertentu untuk memukau pendengar. Ini menyebabkan hati pemuda sentiasa terpanggil-panggil pergi ke rumah atau kampung penganjur gendang Melayu. Pemuda yang bertandak nopeng, selain berusaha menunjukkan ketampanannya dan mengorat anak dara, mereka juga bertandak untuk menunjukkan bakatnya. Adalah suatu yang memalukan, sekiranya pemuda Melayu tidak tahu atau kekok bertandak nopeng.

bersegilaan pemuda terhadap gendang Melayu kekal hingga sekarang. Dahulu wan pan, tetapi sekarang bermotorsikal. Dahulu, badan mereka berbau minyak

wangi, tetapi sekarang berbau arak. Dahulu, mereka bertandak nopeng dengan 
gaya yang mengasyikkan, tetapi sekarang bertandak tanpa rentak. Kini, permainan gendang Melayu semakin tercemar." Titik hitamnya telah terpatri sejak 1920. an dan 1930-an lagi. Ia dinukilkan oleh Rakawi Yusuf dalam novelnya, Melati

\section{Sarawak.}

\section{BAHAYA GENDANG MELAYU}

Rakawi Yusuf hidup sezaman dengan kerancakan permainan gendang Melayu. Ini membolehkannya mengkritik permainan gendang Melayu dengan 'sehidup. hidupnya'. Melati Sarawak merakamkan segala kritikannya terhadap permainan gendang Melayu dengan jelas dan tegas. Ia ditulis berdasarkan pengalaman dan pengamatannya. Rakawi Yusuf menyifatkan permainan gendang Melayu sebagai 'perkara yang terutama sekali meracunkan kesuburan anak-anak muda dalam hal hendak meninggikan mutu' bangsa dan nusanya. ${ }^{12}$

Rakawi Yusuf juga menentang permainan gendang kerana ia menjerumuskan pemuda-pemudi 'tergelincir kepada perbuatan yang cemar yang tiada disukai oleh pergaulan hidup dan dikutuki oleh syariah'. Gendang Melayu merupakan 'punca yang mengalirkan beberapa cawangan yang memimpin kepada jalan kerosakan, kehinaan dan kemunduran bangsa'. Bahkan, ia juga 'meluaskan jalan bagi kesuburan hidup benih cinta keinginan di antara laki-laki dengan perempuan' yang tidak berlandaskan syariah Islam. ${ }^{13}$ Oleh itu, bagi Rakawi Yusuf 'sepatutnyalah bagi mereka yang tertua umurnya dan yang tertinggi pengetahuan dan telah banyak perjumpaan dan pendapatannya itu' bersatu menyekat permainan gendang Melayu.

Rakawi Yusuf prihatin dengan nasib dan masa depan golongan pemudapernudi. Mereka merupakan 'tiang negara dan harapan bangsa'. Rakawi Yusuf sedar bangsanya akan punah jika akhlak pemuda-pemudi rosak binasa. Kelalaian dan kelekaan mereka akan mencemarkan maruah bangsa. Rakawi Yusuf mahu masyarakatnya menyedari hakikat ini. Ini mendorong beliau mengingatkan masyarakatnya tentang bahaya permainan gendang Melayu. Ia dinyatakannyz menerusi dialog Yasin dan Harun :

Bukannya kaum laki-laki sahaja yang rosak dari pekerjaan ini (gendang Melayu), cousin ! [kata Yasin kepada Harun] Bahkan kaum ibu itu terlebih rosak lagi. Pendeknya, pada fikiranku jikalau kaum ibu lagi di dalam keadaan rosak binasa itu, walau bagaimanapun keteguhan dan kesempurnaan kaum laki-lakd, nescaya binasa juga kerana adalah boum 
ibu ialah guru yang pertama bagi kanak-kanak. Lagipun, mereka itu diumpamakan seperti "kemudi" dan kaum laki-laki seperti "bahtera". Oleh yang demikian bagaimanapun teguh dan cukup kelengkapan bahtera itu belayar tak bertali sabut ataupun wayar besi atau berpesawat steam dan motor yang beribu-ribu kuda kekuatannya. Jikalau kemudinya tersangat kecil tiada berpadan dengan bahteranya, apatah lagi jikalau kemudinya memang buruk-rakuk begitu, tidakkah bahtera itu kelak terdampar dan terhempas ke atas beting dan karang dan berpecahbelah?'14

Rakawi Yusuf turut menyifatkan permainan gendang Melayu melalaikan pemudapemudi. Permainan gendang Melayu merupakan acara sepanjang tahun iaitu 'mulai pertengahan bulan Syawal...sampai kepada bulan Syaaban' dan 'bulan Zulhijah ialah waktu tengah jerahnya kulit kambing kering'. Ia diadakan dari kampung ke kampung dan rumah ke rumah hampir setiap malam. Permainan gendang Melayu hanya 'berpuasa' pada Ramadhan sahaja. Ini menyebabkan masa pemuda dan pemudi banyak dibazirkan untuk 'membeli kulit kambing kering' dan berseronok semata-mata. Bagi Rakawi Yusuf, perbuatan seperti ini merugikan bangsanya. Mereka tidak mengisi masa dengan pekerjaan yang memajukan bangsa dan tanah air terutamanya kemajuan pendidikan dan ekonomi. Gambaran tentang keghairahan pemuda-pemudi ketika datangnya pesta gendang Melayu, diungkap oleh Rakawi Yusuf dengan sinis :

Ah. Apa lagi segala pembelinya itu bertempiaranlah di sepanjang jalan seperti tomato terhurai dari tandannya bersaf-saf ada yang derai hilir ke hulu ada yang derai hulu ke hilir dan ada pula yang seberang menyeberang. Pendeknya, dijalan raya dari waktu lepas isya' hingga subuh bermacammacam bau kita dapati iaitu daripada air wangi yang dipakai oleh (saudagar-saudagar) pembeli kulit kambing kering itu dan bermacammacam lagu dan pantun pula boleh kita dengari semalam-malaman itu....atau pada musim inilah jua patut dinamakan 'musim exibition' bidadari dunia bermula dikeluarkan di hadapan mata dan telinga khalayak kerana bertanding rupa dan suara inu kemudian daripada pertapaannya sebulan puasa.'s

Rakawi Yusuf mengecam gendang Melayu kerana ia juga menjejaskan pelajaran dan kesihatan pemuda-pemudi. Keasyikan meraikan gendang Melayu 
menvebabkan tumpuan dan minat terhadap pelajaran terjejas. Akibat tidak cukup tidur, kecerdasan otak terganggu. Badan lemah dan tidak bermaya pada waktu siang. Ia merupakan kesan berjaga sepanjang malam hingga ke pagi kerana dijamu oleh 'kulit kambing kering'. Rakawi Yusuf menyatakannya berdasarkan kesan yang menimpa Harun. Ini menyebabkan Harun insaf menjadi 'saudagar kulit kambing kering' :

[S] egala kerosakan yang parah telah berlaku ke atas dirinya. Kerana dengan sebabnya pelajarannya jadi terpotong kerana otaknya yang bersih taklah menjadi kotor diharu-biru oleh kekuasaan kulit kambing kering. Kecergasan dan kesihatan badannya pun telah menjadi semakin luak oleh keguntungan tidur disebabkan selalu berjaga-jaga malam kerana berdagang kulit kambing kering. Mukanya yang licin lecat telah menjadi cacat dan kerajinannya menghadap pekerjaan pun telah menjadi porakporanda...pendeknya semua perkara yang telah jadi itu datangnya dari permainan gendanglah. ${ }^{16}$

Sikap anti-gendang Melayu dan kepekaan Rakawi Yusuf terhadap bahayanya, kebimbangan terhadap kerosakan akhlak pemuda-pemudi dan peringatannya terhadap mereka, juga terungkap melalui gurindam Harun :

Ya Ilahi Malik Udayyan

Peliharakan hamba-Mu yang daif pengetahuan

Pancainderaku tidak ketahuan

Adakah ia dirasuk syaitan.

Allahu Akbar Khalikul Alam

Peliharakan hamba-Mu siang dan malam

Perasaan laksana timbul tenggelam

Terminum racun gadis pualam.

Ilahi Rabbi Allahu Akbar

Serasa belayar angin yang gubar

Tali-temali jikalau langgar

Nhirnya layar habis bertebar.

Ya Allah Khalikul Manan

Hamba-Mu sedang dalam ayunan 
Gelombang asyik mengambil zaman

Tumbuh seperti tanam-tanaman. ${ }^{17}$

\section{PEREMPUAN GENDANG}

Rakawi Yusuf juga mengecam sikap perempuan gendang. Mereka dikatakan 'menurut kehendak hatinya menggunakan segala pantun-pantun yang keji yang tiada senonoh bunyi'nya. Bagi Rakawi Yusuf, pantun yang diperdengarkan oleh perempuan gendang sebenarnya 'terbit atau lilih daripada lautan asyik berahinya'. Ia merupakan punca yang menyebabkan Harun :

[M] erasai lemas...tidak dapat bernafas dan menggigit-gigit jari telunjuknya...menunggang dahinya dengan dua-dua tangan sebentar, kemudian bangkitlah pula berjalan-jalan di beranda anjung sambil memecal-mecal dadanya seolah-olah menghidap satu penyakit yang sulit rupanya. ${ }^{18}$

Ini adalah kesan gendang Melayu dan pantun yang ditulis oleh Aminah kepadanya. Tiga rangkap pantun tersebut tercatat dalam pocket book Harun. Ia turut dibaca oleh Yasin. Bagi Yasin, ia hanyalah lumrah dalam percintaan. Ia tidak seharusnya menyebabkan Harun resah-gelisah. Ini menyebabkan Yasin mentertawakan Harun. Namun, bagi Harun, ia menjadi racun yang bisa mengalir dalam urat dan darahnya. Fikiran dan jiwanya tidak tenang akibat pantun tersebut. Pantun tiga rangkap itu berbunyi :

Perahu baru temirang baru Baru sekali masuk Melaka Abang baru adik pun baru Inilah baru bertentang muka.

Ke padang berlumba kuda Ke Satuk jambatan gantung Demi terpandang wajah kekanda

Hati beramuk dengan jantung.

Ayam mengeram di atas atap Pecah seekor sayz turunkan 
Benar pun haram di dalam kitab

Abang seorang adik pohonkan. ${ }^{19}$

Rakawi Yusuf mengkritik secara halus penampilan perempuan gendang Melayu. Mereka digambarkan oleh Rakawi Yusuf sebagai penggoda, seksi dan mengeliurkan asmara darah muda. Ini menyebabkan Harun, sebagai mewakili pemuda Melayu, tergila-gila akan Aminah, yang mewakili perempuan gendang Melayu. Dalam satu sindirannya, Rakawi Yusuf menggambarkan godaan Aminah melalui pujian Harun :

Amboi, cousin ! [ Yasin ] Pandai sungguh dia ( Aminah ) bergendang. Lagipun pada malam itu entah apakah petua guru yang dibawanya dan minyak apakah yang dipakainya. Aku ( Harun ) lihat adalah keelokannya pada malam itu akan menyamakan keelokan "Queen of Sheeba", kerana dianya ( Aminah ) nampak terus tiada berlindung barang sedikit pun jua. ${ }^{20}$

Sambil itu, Harun menyindir :

Bukan cousin tak tau kebiasaan orang-orang kita pada waktu bergendang itu direntangnya tirai daripada kain kasa dan dipasang api elektrik terang benderang.... .

Rakawi Yusuf juga mengecam godaan perempuan gendang yang amat berbahayz kepada pemuda. Rakawi Yusuf mengingatkan golongan pemuda agar menjauhkan diri daripada mereka. Selain berwatak penggoda, mereka juga menjadi agen perosak akhlak pemuda. Ia dinyatakannya melalui episod percintaan Harun dan Aminah. Perasaan cinta Aminah terhadap Harun menyebabkan Aminah bertekad menggamit cinta Harun. Aminah menyedari sukar baginya meraih cinta Harun kerana 'Si Harun itu seorang muda yang beradab lagipun sangat memperhargaken dirinya [dan] tiadalah pernah ia berperangai seperti anak-anak muda yang lainlain yang selalu gugur maruah'. ${ }^{22}$ Tetapi, Aminah tetap tidak berputus $25 s$. Seba simbol perosak pemuda, Rakawi Yusuf memancarkan niat serong Aminath melalui kata-kata angkuhnya : 
daripada segantang madu. Giginya yang berkilat-kilat seperti perak terupam bersumbi pula dengan emas paun ikat cara crown memancar-mancarlah cahayanya bersabung dengan cahaya matanya seperti bintang marikh menikam. nikam kepada Si Harun tambah lagi duduk tiadalah menyenget barang sedikit jua pun melainkan lurus tepat. Hai ! Teruna yang mana juga tak hancur hati manakala menatapi akan segala kehebatan susuk badan si gadis yang comel... [y] ang sengaja didedahkannya itu.

Pada semalam-malaman bermain gendang itu tiadalah dapat Harun hendak mengedarkan teropong panjangnya ke lain direction hatta satu degree sekalipun melainkan tetaplah mengompas kedudukan dua buah ( pulau mutiara) yang tumbuh bertimbalan menendang baju di dada Aminah. ${ }^{25}$

Cara berpakaian Aminah dikecam oleh Rakawi Yusuf :

Maklum[lah] pakaian perempuan pada zaman baru-baru ini pada ralibnya berjual badanlah... adalah kelakuan perempuan-perempuan kita zaman sekarang pada zahirnya bersopan tetapi pada batinnya mengumpan...Ya ! Bukanlah juga seperti umpan mengail ikan atau hanyalah seperti kata bidalan 'seperti kucing dengan ikan panggang' atau (ikan ngantung - kucing mingung).

Betapa tidak - cubalah perhatikan dari pakaian mereka-mereka [ perempuan gendang ]. Bukankah tapihnya semakin singkat sampai ke bawah lutut sedikit saja ? Apa adakah saudagar-saudagar kain batik di tanah Jawa sana telah mengurangkan sukatan (saiz) kain-kain batik itu daripada biasanya ?

Baju-baju mereka pun semakin sempit dan ketat di badan dengan pendeknya pula sehingga dibiarkan saja punggungnya yang bulat-bulat seperti digiling itu bergegar-gegar dibawa berjalan dan putik delima sepasang melekap di dada itu dibiarkan saja bergala-gala nampaknya menjadi hak mata dan memanaskan darah keinginan yang memang sedia tertanam di dalam kalbu manusia sehingga? mengerodak buihnya meruap....26

Perubahan cara berpakaian wanita Melayu umumnya dan di kalangan perempuan gendang khususnya, amat menggusarkan Rakawi Yusuf. Beliau menyifatkan masyarakatnya sedang dirempuh oleh 'lautan zalimat' yario alow 'mencemarkan pergaulan umat'. Rakawi Yusuf melihat ia berpunca daripada permainan gendang Melayu yang menyebabkan wujudnya 'penyakit berahi... yang 
tiadalah sekali-kali dapat diubati oleh tabib-tabib yang faham sekalipun' melainkan :

Dari awan bintang berakit

Awanlah juga jadi bibitnya

Kerana perempuan datang penyakit

Perempuan juga jadi ubatnya. ${ }^{27}$

Bagi Rakawi Yusuf, jika 'penyakit berahi' yang berpunca daripada permainan gendang Melayu tidak dicegah, ia akan menyebabkan kehancuran akhlak pemuda-pemudi. Mereka semakin ketagih dengan permainan gendang Melayu. Ini menyebabkan Rakawi Yusuf meramalkan masa depan bangsanya berada dalam kesamaran. Rakawi Yusuf berharap agar masyarakatnya sedar akan kesilapan mereka sebelum terlambat. Harapannya dinukilkan melalui segugusan doa Harun:

Hai Tuhanku yang Maha Limpah Rahmatnya ! Kasihan apalah kiranya guguri akan anak kunci keinsafan di muka bumi barat laut pulau Borneo ini (Kuching) supaya dipakai membukakan pintu khazanah yang di dalamnya, ada penuh tumpah dengan segala adat istiadat ;ang sia-sia yang tiada memberi manfaat kepada rami [ramai] dan kepercayaan yang karut-karut yang selalu memimpinkan kaumku kepada perangai keborosan dan jalan kepada kehinaan. Mudah-mudahan dengan sebab anak kunci Rahmat-Mu kelak terbukalah pintu gerbang khazanah itu supaya dapatlah udara yang bersih masuk ke dalamnya menghembuskan segala isinya daripada benda yang tiada semenggah darah itu terbang melayang ke daksina dan paksina. Kemudian hamba-Mu pohonkan isi pula khazanah itu dengan itham dan keinsafan supaya boleh segera merentakkan mereka-mereka yang lagi terbenam kakinya di dalam lumpur yang berbau busuk itu. ${ }^{23}$

Kritikan Rakawi Yusuf terhadap 'gendang Melayu' dan 'bilal gendang' turut disalurkannya melalui watak Pak Noraldin. Bagi Pak Noraldin, ayah Harun, yang juga merupakan Pak Ngah Yasin, gendang Melayu 'sangat diseteruinya'. Pak Noraldin mempunyai pendiriannyz tersendiri berhubung bahaya gendang Melayu. Sebagai orang yang lebih berpengalaman dan berpandangan jauh, jelas pandangannya terhadap bahayz gendang lebih meluas berbanding Harun. Pak 
Noraldin menyifatkan gendang Melayu sebagai punca kerosakan akhlak pemuda. pemudi, mencemarkan maruah Islam dan meragut kesucian anak dara. Sepert tegasnya :

[G]endang Melayulah yang menyebabkan kerendahan mutu bangsa kita apakala berbanding dengan bangsa-bangsa asing dan meninggalkannya ke belakang di dalam perkara perlumbaan hidup...melencongkan jalan kaum laki-laki kita yang rupa-rupa hendak lurus itu dibawanya ke longkang sehingga orang alim kita pun tak dapat menggerakkan bibirnya, menutup dan memakukan segala kitab hadisnya di dalam sarah (peti)...jangan-jangan hendak dijual diberi percuma pun orang tak mahu.

Demikian jualah anak-anak perempuan yang bergendang itu manamana yang pandai membawa bermacam-macam lagu dan suaranya yang merdu-merdu itu geramlah hati laki-laki mendengarnya kadang-kadang sampai jadi 'demam unggui....akhirnya kelak terjaring juga kubu si gadis itu. Tidakkah begitu ? Banyak sudah yang kutau ( telah diterobosi) kubukubu 'sheikh gendang' itu terjaring mentah. ${ }^{29}$

Rakawi Yusuf menyifatkan 'sheikh gendang' apatah lagi yang tidak berpendidikan, seperti tuma kerana 'melindungkan [menyembunyikan] kepalanya saja' sedangkan 'pantatnya [punggung] tertinggal diluar tidak dihiraukannya'. la bertepatan dengan sikap mereka ketika diorat oleh pemuda. Mereka 'lekaslah berlindung dan memasang kompas halus di celah-celah papan atal jendela....jikalau ditengah lapang tangannyalah dipakai melindungkan mukanyz'. Tetapi, 'kompas halusnya tiada juga dibuang diteluskan juga di celah-celah jarinya'.,0 Inilah hakikat sikap 'supan tuma' dan kepura-puraan 'sopan-sanunnyz' perempuan gendang yang kononnya dikatakan tidak melanggar undang-undang syariat. Bagi Rakawi Yusuf, perbuatan tersebut juga tidak ubah seperti 'pemburu dengan burung kasawari'. 3" Namun, bagi anak perempuan yang berpendiditan. 'kecutlah semua kutu-kutu jalan dan tiadalah berani menghampirinya'. "." Mereka terselamat daripada usikan dan gangguan kerana disegani oleh kutu-kutu jalan. Oleh Itu, pendidikan Barat bukanlah mencemarkan akhlak dan marvat perempuan seperti yang disangkakan oleh sesetengah ibu bapa. Sebalikuty's pendidikan dan ilmu pengetahuan menjadi perisai kepada anak peremputa
merela. 
Rakawi Yusuf juga menyingkap permainan gendang Melayu dari perspektif Islam. Bagi Rakawi Yusuf, unsur-unsur 'keghairahan' yang terdapat dalam pantun gendang Melayu, melanggar batas Islam dan tata susila Melayu. Ini membimbangkan Rakawi Yusuf. Ketika itu, perempuan gendang Melayu semakin tandus dengan nilai kesopanan dan kesantunan. Ini menyebabkan Rakawi Yusuf menyelar secara halus sikap Aminah yang tidak lagi mempertahankan harga dirinya. Aminah tidak berasa segan-silu menukilkan pantun yang 'asyik berahinya' kepada Harun dalam satu majlis gendang Melayu. Bagi Rakawi Yusuf, pantun tersebut menjadi 'tiga titik racun yang bisa' kepada Harun. Bantahan Rakawi Yusuf terhadap gendang Melayu sememangnya keras. Lantaran itu, Rakawi Yusuf berharap agar 'kambing tak boleh hidup lagi di dalam negeri ini supaya tidak didapati kulitnya lagi' untuk dibuat gendang.

\section{PEMIMPIN MELAYU DAN PENGELOLA GENDANG}

Selain mengkritik permainan gendang Melayu dan perempuan gendang, Rakawi Yusuf juga membidas sikap masyarakat yang menyokong permainan gendang. Protesnya tidak dinyatakannya secara terbuka kerana bimbang 'kita kelak [akan] disakiti oleh orang hati'. Rakawi Yusuf mewakili sebahagian kecil masyarakatnya yang menentang permainan gendang Melayu. Tetapi, sebahagian besarnya pula menyokong. Rakawi Yusuf terkilan dengan pemimpin Melayu dan penganjur gendang yang tidak peka terhadap bahaya permainan gendang Melayu. Ini menyebabkan Rakawi Yusuf mengecam mereka sebagai 'semata-mata merosakkan kehidupan anak-anak muda kita'. Bagi Rakawi Yusuf, sikap tidak peduli pemimpin Melayu juga menyebabkan 'terjatuhlah mutu ( bangsa) manakala bertanding dengan anak-anak bangsa asing. ${ }^{33}$

\section{GOLONGAN TUA}

Bagi Rakawi Yusuf, golongan tua juga menyebabkan keruntuhan akhlak dan kemunduran bangsanya. Mereka merupakan penyokong permainan gendang Melayu. Bahkan, terdapat di kalangan mereka yang menjadi penganjur dan pelatihnya. Mereka mempertahankan permainan gendang Melayu tanpa menyedari bahayanya terhadap masa depan generasi bangsa. la menyebabkan pemuda-pemudi khususnya dan masyarakat Melayu umumnya, terus 'teriaring ke dalam lembah yang sangat ditakuti'. Sokongan mereka terhadap permainan gendang Melayu 
diungkapkan oleh Rakawi Yusuf dengan memetik kata-kata penganjur permainan gendang Melayu :

Pada malam ini sesungguhnya kami berdua laki isteri sangat berasa gemar oleh kehadiran anak-anak dan cucu-cucu semua dengan sudi hati meraikan pekerjaan kami sesungguhnya berserilah majlis pak ngah dan pak wa...dipohonlah kepada dayang-dayang anak cucu semua janganlah aral ralat kepada rasa, janganlah bermalu-malu asam buatlah sebagaimana keadaan di dalam rumah sendiri. Sekarang silalah semua membuka suara bergendanglah dengan sebenar-benar dan berpantunlah dengan sepuas-puas hati supaya gemeralapan cahaya majlis pak wa pada malam ini...semuanya itu daripada mereka-mereka ( pemuda) dahaga akan permainan tandak ... raikanlah mereka akan hati mereka-mereka. Demikian jua induk-induk bapa tua-tua yang ada duduk di situ semuanya suka mendengar anak-anak buahnya bergendang dan berpantun menyindir-nyindir bujang-bujangan itu. ${ }^{34}$

Dalam klimaks plot novelnya, Rakawi Yusuf mengukuhkan pandangannya terhadap bahaya permainan gendang Melayu. Ia dinyatakannya menerusi 'kejadian di kebun bunga'. Rakawi Yusuf menggambarkan Harun sebagai pemuda yang setia. Tetapi, Aminah pula mengkhianati percintaannya dengan Harun. Sepeninggalan Harun, kerana melawat kawasan pesisir, Aminah menjalinkan hubungan dengan Omar, 'saudagar kulit kambing kering'. Ketika berada di kebun ayah Aminah untuk meneruskan pembinaan rumah barunya, Harun ternampak Aminah dan Omar sedang berkhalwat. Harun begitu kecewa apabila melihat 'senyuman simpul dan syoknya oleh senda dan gurau' antara Aminah dan Omar. Harun juga kecewa kerana 'ketiadaan bersih cinta dan ketiadaan teguh setia' Aminah terhadapnya. yang kekal pada sisinya' tidak kesampaian 35 . Aminah bergegas melarikan diri ke rumahnya. Omar pula begitu marah dengan
Harun kerana 'kebiasaan racun yang lagi'. Harun terbabit dalam pergaduhgunginya belum dapat penawarnya menumpaskan Omar dengan 'kuntau jitsu' kecil dengan Omar. Setelah Takaporo selama enam bulan, Harun menasiho dipelajarinya daripada Mr. tajam menikam. Ia bukan ditujukan menasihati Omar dengan kata-kata yang 
kesemua pihakyang masih belum menyedari 'bahaya' permainan gendang Melayu

Hai Encik Omar ! Kenapa seperti orang kehilangan akal ? Apa tidakkah tuan ketahui yang kita ini bersifat manusia ? Di manakah perangai kemanusiaan itu tuan tinggalkan ?...Kenapa begitu jahat pekerti tuan dari fasal sedikit atau perkara yang sangat keji itu tuan dengan sertamerta naik jaki dan dengan gembira hendak mengadakan suatu peperangan yang tidak layak diadakan lagi pada zaman ini ?

Sekiranya tuan hendak juga menurut nafsu syaitan itu bolehlah juga saya melayaninya tetapi saya pohon janganlah diadakan pada waktu ini dan di dalam tempat ini...Sekiranya kita buatkan di sini pada waktu ini juga tiada syak lagi tentulah pecah khabarnya kelak di sekeliling bandar ini mengatakan perkelahian di antara kita ini terjadi kerana berebut perempuan. Apa tidakkah malu ? Kerana bukanlah malu itu bagi kita berdua saja bahkan segala ibu bapa dan kaum keluarga bagi kedua pihak pun termasuk sama.

Demikian jua bagi Pak Jalil kita seorang yang terkenal juga kehormatannya. Alangkah malunya kerana anaknya yang tunggal lagipun seorang gadis yang mempunyai keelokan dan kebersihan namanya itu telah menjadi kotor dan busuk baunya kerana menyebabkan kedatangan bahaya di atas kita ini dan sentiasa sajalah kelak di bibir-bibir orang merebak ke sana sini dan dengan sebab itu barangkali menyebabkan anaknya itu tiada dipinang orang atau...Janganlah menurut wap darah kemudaan yang panas supaya kita jangan tertolak keluar sempadan kemanusiaan yang mempunyai tadbir lebih luas daripada binatang.... ${ }^{36}$

Aminah juga terpaksa menanggung akibat perbuatan serongnya. Pertama, dia mengingkari permintaan Harun agar meninggalkan lubuk gendang Melayu. Kedua, dia tidak menghargai 'kebersihan dan kesetiaan' cinta Harun terhadapnya. Peristiwa tersebut menyedarkan Aminah tentang kesilapannya dan kepurapuraannya. Ia berpunca daripada permainan gendang Melayu. Aminah hampirhampir menjadi mangsa Omar. Kedatangan Harun menyelamatkannya daripada terjerumus ke lembah kehinaan. Aminah menyesal atas perbuatannya. Katanya dengan penuh sesal :

Hai - sesungguhnya pada hari ini telah datanglah 'celaka' menghinggapi badanku apakah jadi aku ini kelak ? Kerana rahsiaku telah diketahui 
oleh Harun. Tentulah dia terlebih renggang lagi hatinya akan daku sedang aku tiada mengikut katanya menyuruh berhenti daripada bergendang pun dia sudah renggang konon apa telah terlanggar di matanya sendiri takkah putus sama sekali tali ikatannya ? Jikalau demikian adanya hampirlah aku ini kelak mengikut sebagaimana teladan kawanku yang telah lalu (yakni mengepit bungkus)..$^{37}$

Selain Aminah, ibu bapanya juga mula menyedari bahaya permainan gendang Melayu. PakJalil menganggapnya sebagai punca 'banyak pergaulan'. Beliau juga sering mendengar 'segala perkataan yang kurang baik' dan 'sebut-sebutan orang akan anak'nya. Pak Jalil sedar ia berpunca daripada penglibatan Aminah sebagai 'sheikh gendang'. Ia membuka laluan pergaulan bebas dan menyebabkan anaknya menjadi sasaran fitnah. Ini menyebabkan Pak Jalil mengambil keputusan mendirikan rumah jauh dari kawasan bandar. Ia bertujuan menjauhkan diri daripada angin fitnah. Keputusan itu turut dipengaruhi oleh masalah udara yang tercemar di kawasan bandar. Bagi Pak Jalil, perpindahan itu juga dapat mengeratkan hubungan kekeluargaan seperti 'orang berpuasa [yang] radang nafsunya akan barang makanan' ${ }^{38}$

Ekoran daripada 'peristiwa di kebun bunga', Rakawi Yusuf mengukuhkan pendiriannya berhubung penentangannya terhadap gendang Melayu. Beliau menyifatkan permainan gendang Melayu sebagai punca tertanamnya 'baja yang sangat menyuburkan kehidupan perkahwinan sulit' dan 'nikah salah'. Ia juga 'sangat keji bunyinya' seperti 'nikah sulit' yang 'selalu menjatuhkan air mata kerana mengentas rasa ibu bapa akan anaknya' yang terbabit dengan 'perkara yang sangat dibenci oleh perhimpunan manusia [zina]'. Lantaran itu, Rakawi Yusuf menyifatkan permainan gendang Melayu menyuburkan 'perkara-perkara kerosakan pada zaman yang telah lalu dan akan datang [yang] menimpa ke atas anak-anak muda'. Ia juga menyebabkannya 'benci akan segala adat istiadat kaum bangsanya dan kerendahan mutu kaum ibu di negerinya', ${ }^{39}$ Ini mengukuhkan lagi kebencian Rakawi Yusuf terhadap permainan gendang Melayu. 12 dinyatakannya menerusi perasaan kesal Harun terhadap kecurangan Aminath Melayu :

Dengan peringatan yang semakin diingat semakin bertambah-tambalh banyaknya itu telah memberwa kepada suatu perasean atau menjadi udare 
yang tak baik kepada Si Harun kerana menghantarkan bau yang busuk ke hidungnya sehingga datanglah benci di hatinya akan kerosakan kaum bangsanya yang tiada seorang jua pun daripada mereka mengambil perlu pada berusaha mencari jalan yang boleh menyekatkan perkara yang mendatangkan kerosakan kepada bangsa itu [Melayu]. ${ }^{40}$

\section{CARA PENYELESAIAN}

Bagi Rakawi Yusuf, gendang Melayu perlu dilenyapkan sehingga ke akarnya. Jika tidak, ia akan terus merosakkan pemuda-pemudi secara halus. Masyarakat umum tidak begitu menyedarinya. Tetapi, Rakawi Yusuf pantas mengesani racun yang tersembur melalui gendang Melayu. Bagi mengatasi masalah kerosakan akhlak dan memimpin masyarakatnya ke arah kemajuan, Rakawi Yusuf mengemukakan empat langkah utama. Pertama, Rakawi Yusuf menyeru semua lapisan masyarakatnya bersatu dan berganding bahu menyekatnya. Mereka terdiri daripada pemimpin, ulama, golongan terpelajar, ibu bapa, pemuda dan pemudi. Kedua, sekolah agama perlu didirikan untuk lelaki dan perempuan. Mereka perlu dididik dengan ajaran Islam dan nilai kemelayuan. Ia dapat melahirkan generasi yang memahami hukum-hakam Islam dan memelihara kesucian diri, agama dan bangsa. Ketiga, Rakawi Yusuf juga menyarankan agar anak gadis segera dinikahkan apabila sampai waktunya yang sesuai 'sementara belum perkara yang keji-keji datang menenggek'. Baginya, 'menyimpan perempuan muda itu sangatlah besar bahayanya'. Ini kerana 'anak-anak muda [pemuda] kita di kampung-kampung itu belumlah tahu mereka-mereka menjaga maruah, kehormatan dan kebersihan dirinya [dan] manakah pula dapat ia hendak menjaga kehormatan dan kebersihan anak-anak dara orang ?'. Bagi Rakawi Yusuf, pemudapemuda Melayu ketika itu masih belum berkesedaran. Mereka tidak memahami konsep persaudaraan Islam dan maruah sebagai umat Islam. Sebaliknya, pemuda menganggap 'tiap-tiap perempuan itu menjadi musuhlah kepadanya dan sentiasalah mereka-mereka memberang'."' Keempat, persatuan khas untuk pemuda dan pemudi juga perlu ditubuhkan. Ia bertujuan menyatukan pemudapemudi, memberikan kesedaran dan menggerakkan mereka ke arah kemajuan berasaskan Islam. Melalui aktiviti persatuan seperti kegiatan keilmuan dan keagamaan, ia dapat memelihara adab dan hubungan pemuda-pemudi. Kesemuanya ini diungkapkan oleh Rakawi Yusuf menerusi dialog antara Yasin dan Pak Noraldin. Ia merupakan penutup novel dan kemuncak pemikirannya : 
Yasin - Pada pengertian saya, Pak Ngah, dalam perkara ini sesungguhnya tiadalah sekali-kali dapat hendak dibuang atau disekatkan dengan sertamerta kerana adalah permainan itu telah tumbuh dengan sangat-sangat suburnya dan telah menjadi satu makanan yang sabaikh ( yang tiada dapat ditinggalkan ) kepada mereka. Oleh tiadalah dapat berjaya pembunuhannya itu jikalau dengan dipotong-potong dahannya saja melainkan dibunuh akar manahnya.

Pak Noraldin - bagaimana jalan hendak membunuh akarnya itu kerana pokok tanaman orang masakan mau memberi kita mengorek akarnya?

Yasin - Tidak begitu. Kita tanamkan racun di sekeliling pokok dari jauh-jauh sedikit lama-kelamaan sampai juga pada akarnya.

Pak Noraldin - Apa bangsa racun itu ?

Yasin - Ada pun racunnya, itu tiada lain daripada mengadakan sekolah-sekolah agama bagi kanak-kanak laki-laki dan perempuan kerana apabila masing-masingnya kelak telah asyik dengan pelajaran khusus dalam hal kebersihan jalan agama nescaya adalah juga berkurang permainan itu di belakang hari.

Dan lagi patutlah diadakan satu persekutuan bagi anak-anak muda kita berhaluan kepada agama pada se-Jumaat sekali diadakan khutbah pada malam hari khas bagi menerangkan kebersihan agama dengan segala kotor-kotor yang menghinggapi akan dia ataupun diboycott sama sekali permainan gendang perempuan itu. Jika boleh berlaku tujuantujuan sedemikian saya percaya walaupun tiada segera hilangnya tetapi di masa sepuluh atau lima belas tahun di belakang kelak akan-akan mupuklah juga lenyapnya.

Pak Noraldin - Tujuan itu sangat-sangat elok tetapi sukar kerana besar belanjanya. Sekiranya ada seorang dua mau menyokong pekerjaan ini bolehlah aku belanjakan setengah daripada hartaku dalam perkara
ini."

Berdasarkan perbincangan ini, jelas Rakawi Yusuf menyasarkan kritikannya terhadap gendang Melayu tanpa mengkesampingkan aspek yang lain. Kritikaniry dikaitkannya sebagai gelongang' pula, mencakupi watak dan perwatakannya. Ini diekori oleh golongan pemun pemudi yang mengalami virus keruntuhan akthak gendang Melayu. la menjadi semalunca utama kepada masalah ini pula iale besar' dalam masyarakatnya semakin parah kerana tidak dicegah oleh 'or2us yra. Jika diamati kanta pemikiran Rakawi Yusuf, jeles 
beliau melihat adat dan budaya Melayu dengan kaca mata Islam. Ini menyebabkan Rakawi Yusuf berani menentang adat dan budaya bangsanya. Beliau mempunyai hujah tersendiri menentang 'gendang Melayu' berdasarkan syariah Islam. Ia menjadikan penentangan Rakawi Yusuf terhadap gendang Melayu sebegitu kukuh. Beliau menggunakan Islam sebagai sandaran pemikirannya dan usahanya menyedarkan masyarakat Melayu ke arah kemajuan. Pemikirannya ini semakin jelas apabila Rakawi Yusuf mengemukakan pembinaan sekolah agama dan pertubuhan keagamaan bagi memimpin masyarakatnya ke arah kemurnian Islam. Rakawi Yusuf bukan sekadar menggunakan kaedah dan teras Islam sebagai jalan penyelesaiannya, malah menjadikan Islam sebagai asas kehidupan dan kemajuan bangsanya.

\section{PEMIKIRAN RAKAWI YUSUF TERHADAP ASPEK LAIN}

Rakawi Yusuf tidak mengkritik gendang Melayu semata-mata. Menerusi Melati Sarawak, beliau turut menyelitkan kritikannya terhadap aspek lain. Ini menyebabkan Melati Sarawak menjadi lebih menarik. Ia juga menunjukkan pemikiran Rakawi Yusuf yang kaya dengan pelbagai kritikan. Beliau menyusun kritikannya sesuai dengan plot, watak dan tema yang dibincangkan. Tetapi, artikel ini tidak membincangkan pemikiran Rakawi Yusuf mengikut plot, watak dan tema. Ia dibincangkan berdasarkan tema pemikiran Rakawi Yusuf. Ia bertujuan menyoroti kerangka pemikiran Rakawi Yusuf dengan lebih tersusun dan mudah difahami.

\section{KEPENTINGAN ILMU DAN PENDIDIKAN}

Rakawi Yusuf mencintai ilmu pengetahuan. Beliau menggalakkan masyarakatnya menuntut ilmu dalam pelbagai bidang : dunia dan akhirat. Ia diterapkan oleh Rakawi Yusuf melalui watak Harun disamping Yasin dan Nahariah. Bilik Harun digambarkan tersusun rapi dengan buku. Harun juga merupakan anak muda yang bercita-cita tinggi, minat belajar dan membaca pelbagai bahan termasuk buku bahasa Inggeris. Rakawi Yusuf melukiskan watak dan perwatakan Harun sebagai contoh kepada pemuda-pemudi Melayu. Lebih-lebih lagi dalam keadaan kesedaran masyarakat Melayu terhadap kepentingan pendidikan yang belum begitu meluas, apatah lagi pendidikan Barat. Sebaliknya, mereka lebih suka berfoya-foya terutamanyz menyahut panggilan 'gendang Melayu'. 
Rakawi Yusuf mahu masyarakatnya maju dalam bidang pendidikan. Beliau menggalakkan mereka menuntut ilmu hingga ke seberang laut untuk menjadi doktor, peguam dan majistret. Beliau juga menuntut agar anak perempuan juga diberikan pendidikan tinggi. ${ }^{43}$ Mereka wajar dihantar ke seberang laut menuntut ilmu. Ilmu yang mereka perolehi dapat digunakan untuk memelihara kehormatan diri, keluarga dan rumah tangga. Rakawi Yusuf mahu masyarakatnya mencontohi kejayaan anak perempuan di Tanah Melayu dalam aspek pendidikan. Baginya, ilmu penting kepada wanita 'supaya boleh ia mendapat dan pelajaran di dalam hal agama dan bangsa dan menjadi guru sekolah perempuan' di Sarawak kelak. Saranan dan hasrat Rakawi Yusuf mempunyai asasnya tersendiri. Rakawi Yusuf menyalurkannya melalui penjelasan Pak Noraldin :

[A]dalah pada fikiranku perempuan yang boleh menjadi guru sekolah ialah perempuan-perempuan yang sudah bersekolah lagi terpelajar dengan pelajaran agama dan terlatih dengan adat kebangsaan yang bersetuju dengan masanya terutama lagi di atas kehendak-kehendak yang hendak meninggalkan adat-adat yang telah mendatangkan beberapa banyak merbahaya atas kehidupan dan kebersihan agama dan bangsa kita pada zaman tamadun ini dan hendak pun digunakan perempuanperempuan bangsa asing buat mengajar anak-anak perempuan bangsa kita, boleh jadi ? Ya ! Boleh ia mengajarkan di dalam hal baca membaca, tulis menulis dan songket menyongket...tetapi bolehkah dia mengajarkan di dalam perkara adat kesopanan perempuan seperti yang dikehendaki oleh syariah dan segala tata tertib kesopanan kebangsaan kita? Tentu
tidak."

Rakawi Yusuf mengisytiharkan dirinya sebagai golongan Kaum Muda. Ia diselitkannya melalui pendirian dan tindakan Pak Noraldin. Beliau tidak Pak Noraldin tidak merakat terhadapnya sebagai berfahaman Wahabi. Malah, menghantar anaknya (Hanjak daripada pendiriannya. Pak Noraldin tetap Yusuf, pendidikan tetap pentin Nahariah) ke sekolah mubaligh. Bagi Rakawi di mata akan segala tingkahting kepada anak perempuan kerana 'sedap sajalah ganggu barang sedikit jua pun'."' Teton pekerjaannya [dan] sesungguhnya tiadalah terhadap Pak Noraldin kerana ". Tetapi, masyarakat setempat memandang serons melanggar undang-undang syariah Kaum Tua, mereka menyatak agama Islam...' Bagi pihak yang berfahaman perempuan tiada boleh diajer 
menulis... kerana memudahkan dianya berbuat jahat'. Tetapi, ia tidak mematahkan semangatnya. Pak Noraldin sedar ilmu wajib dituntut hatta dengan orang bukan Islam. Baginya, menghantar anaknya ke sekolah mubaligh tidak merosakkan aqidah dan akhlak, asalkan mereka diberikan didikan dan kefahaman Islam. Sebaliknya, anak muda yang kurang berpendidikan nampaknya lebih cenderung rosak akhlaknya. Seperti yang ditegaskan oleh Pak Noraldin :

Astaghafirullah ! Bukannya diberi bebas bercampur gaul dengan lakilaki ataupun melampaui daripada had sepatutnya ? Dan lagi mana-mana perempuan yang telah tercebur ke dalam lubuk kecabulan itu tiadalah seorang pun jua daripadanya ada mempunyai pengetahuan tulis menulis dan semua pencabulan yang telah jadi di antaranya itu kebanyakannya daripada wasilah 'gendang'...6

Rakawi Yusuf mahu pemudi zamannya mempertahankan maruah dan kesucian diri. Baginya, wanita yang berpendidikan tidak mudah terjerumus ke lembah kehinaan. Mereka disegani dan dihormati sebagai perempuan berpelajaran. Tetapi, beliau amat bimbang dengan nasib dan masa depan perempuan gendang yang kurang berpelajaran. Mereka mudah terjebak dengan pujuk rayu pemuda. Mereka menjadi sasaran usikan dan oratan pemuda yang ingin memuaskan nafsunya. Ini menyebabkan 'sungguhpun teguh kubu dan kota syeikh-syeikh gendang itu tetapi banyak sudah tertawan dengan senang saja'. Kebimbangan Rakawi Yusuf dipancarkannya melalui sepucuk surat yang diberikan oleh Harun kepada Aminah :

Sungguhpun demikian manakala kakanda insaf akan segala kerosakan yang telah jadi ke atas diri kakanda tertahanlah kaki kakanda hendak berjalan ke lorong itu. Tambah pula kakanda berasa lemas oleh mendengar nama adinda di mulut-mulut tiap-tiap pembeli kulit kambing kering...memuji-mujikan keelokan rupa dan kesedapan suara dan gerinik adinda belaka. Pendeknya semuanya ada simpan hati [kepada] adinda.

Oleh itu kakandz pohonkanlah dengan seboleh-bolehnya berhentilah adinda daripada pekerjaan itu dari hari ini dan kemudian daripada enam bulan kelak bolehlah kakanda rundingkan dalam hal perjodohan kita dan dari harl ini jikalau adinda masih lagi bermain gendang bahawrsanya janganlah adinda tingas-tingasen dan cari-carian 
akan kakanda sekiranya jikalau tiada hadir di dalam majlis yang kakanda sudah sumpah kepadanya itu. ${ }^{47}$

\section{PENDIDIKAN ANAK}

Rakawi Yusuf menyelar ibu bapa yang terlalu memanjakan anak. Rakawi Yusuf mahu ibu bapa mendidik anak mereka dengan tegas. Ini diwakili oleh ayah Harun, Pak Noraldin. Bagi Rakawi Yusuf, terlalu memanjakan anak merupakan kaedah mendidik anak yang kurang berkesan dan menyebabkan anak menjadi 'bertembung laku'. Ia diwakili oleh ibu bapa Aminah. Ini menyebabkan Aminah, tanpa segan-silu, menghisap 'cigarettenya bangsa embassy berulam air koko' di hadapan Mak Jijah, sambil duduk 'tersandar di kerusi rotan yang berwarna hitam puth berselang seli sebun dengan asap rokok'nya. Bagi Rakawi Yusuf, tingkah laku Aminah berpunca daripada 'sangat dipermanjakan oleh kedua-dua ibu bapanya' ${ }^{48}$ Ia juga menyebabkan Aminah 'sangat terkurang di dalam perkara mahauga menjagakan kehormatan keperempuanannya...terkebawah benar mutunya jikalau diuji dalam perkara adab kesopanan anak-anak perempuan ${ }^{49}$ dan 'tertinggal kebelakang dalam perlumbaan kemanusiaannya'. ${ }^{50}$ Aminah dan Nahariah hadir dalam dua situasi yang berbeza. Aminah mewakili perilaku pemudi yang tersalah asuhan. Nahariah pula mewaliki pemudi yang berakhlak, diasuh dengan ketegasan dan berbekalkan ajaran Islam. Rakawi Yusuf melukiskan watak dan perwatakan Aminah sebagai sempadan dan Nahariah sebagai teladan. Begitu juga corak pendidikan ibu bapa mereka.

\section{GOLONGAN PERABANGAN}

Rakawi Yusuf juga mengkritik secara halus keistimewaan yang dimiliki oleh golongan perabangan. Mereka menjadi golongan pemimpin dan diberi peluang menjawat jawatan tinggi dalam kerajaan kerana status sebagai golongan aristokrat. Mereka menguasai jawatan dalam Majlis Tertinggi, Majlis Negeri, Balai Datu dan Datu Bahagian. ${ }^{\text {.1 }}$ Anak-anak Melayu kebanyakan pula hanya diberikan jawatan yang rendah. Rakawi Yusuf mahu peluang pekerjaan dinilai berdasarkan kemampuan dan kebolehan. Rakawi Yusuf mempertikaikan kelayakan sesetengah golongan perabangan menjawat jawatan tinggi. Padahal, mereka tidak layak jika dinilai dari sudut pendidikan dan kemampuan. Orang Melayu pula, meskipus mempunyai pendidikan yang lebih tinggi dan lebih berkelayakan, tetapi dinistalean haknya. Dasar Brooke mengekalkan peranan dan kedudukan golong² 
perabangan dalam pentadbirannya berdasarkan darjat sosial, turut dipertikaikan oleh Rakawi Yusuf. Bagi Rakawi Yusuf, sewajarnya semua lapisan masyarakat Melayu dinilai sama rata berdasarkan kelayakan dan kebolehan terutamanya bagi mendapatkan pekerjaan dalam perkhidmatan kerajaan. Rakawi Yusuf menyedari wujudnya dasar diskriminasi dalam pentadbiran Brooke. Dasar Brooke dilihatnya tidak adil bagi keseluruhan orang Melayu. Mereka diketepikan menjawat jawatan tinggi hanya kerana terdiri daripada orang biasa. Bagi golongan perabangan pula, mereka diberikan jawatan tinggi kerana status sebagai golongan perabangan. ini menyebabkan Rakawi Yusuf menyatakan protesnya secara halus terhadap ketaksamaan hak dan taraf bagi seluruh masyarakat Melayu. Inilah keadilan yang terpacak dalam pemikirannya. Rakawi Yusuf mengungkapkannya dengan sinis menerusi dialog antara Harun dan Yasin :

Dua malam yang lepas itu, cousin tak ada di rumah - bukankah ?" (Tanya Harun).

"Ya," jawab Yasin. "Aku pergi ke Rembongan (sebuah jajahan kecil) kerana menyelesaikan land dispute iaitu perkara pergagutan dalam hal perenggan-perenggan (sempadan) kebun di antara orang-orang Cina. Baru petang tadi aku sampai."

"Kena apa cousin pula pergi - bukankah cousin berjawatan sebeya (surveyor) yakni tukang ukur tanah dan bukankah pekerjaan itu tanggungjawab land inspector ?" tanya si Harun.

Jawab Yasin, 'Itu sebenarnya - tetapi land inspector tiada dapat menyelesaikannya, maklumlah semuanya itu (golongan perabangan yang menjawat jawatan tinggi) berpelajaran rendah jadi tiada mengerti apa yang telah diperintah oleh kepalanya (ketuanya iaitu orang putih). Lagipun apabila mereka menulis report tuan kepalanya tidak dapat mengerti apa yang ditulisnya kerana adalah instruction ( perintah ) dari kepala-kepala itu dengan bahasa Inggeris belaka. ${ }^{22}$

\section{KAYA HARTA MISKIN ISLAM}

Rakawi Yusuf turut mengkritik kehidupan masyarakat Melayu yang kaya dengan harta tetapi miskin dengan keperluan Islamnya. Hakikat ini wujud dalam masyarakat Melayu zamannya. Ia digambarkan oleh Rakawi Yusuf melalui keluarga Aminah. Mereka terdiri daripada segilintir masyarakat Melayu yang berada. Pak Jalil 'memang terkenal dengan seorang yang kaya' dan mempunyai 
JURNAL SEJARAH

'kebun-kebun getah yang besar'. Rumahnya diperbuat daripada 'billian daripada fesyen baru. .. berbumbung tiga dan beranjung dua, satu ke hadapan dan satu ke rusuknya....Pintu-pintu dan jendela-jendela semua terlabuh dengan kain jendela bangsa satin yang berwarna merah jambu dan berkendit-kendit dengan reben sutera yang berwarna pucuk pisang diikat serupa necktie'. ${ }^{53}$ Malangnya, Mak Jijah hanya mempunyai sepasang telekung sahaja. Ia merupakan sindirin halus dan tajam Rakawi Yusuf terhadap golongan berada. Meskipun kaya, mereka sebenarnya miskin dengan roh Islamnya.

\section{SIKAP KAUM BAPA}

Akibat kaya dengan harta tetapi miskin roh Islamnya, Rakawi Yusuf menyelar sikap segelintir kaum bapa yang masih tidak mendekatkan diri dengan Allah. Walaupun sudah 'tua langkir' tetapi, nafsunya masih 'muda kera'. Ini dapat dilihat menerusi 'tingkah laku dan stail' mereka berpakaian. Lebih-lebih lagi di kalangan kaum bapa yang berwang. Mereka sentiasa menjadi rebutan kupukupu malam. Rakawi Yusuf tidak menyatakannya secara terbuka. Ia diungkapkannya melalui perasaan syak Mak Jijah terhadap Pak Jalil, suaminya menerusi dialognya dengan Mahruf :

Lagi bangunkah Mak Jijah di rumah ?

Lagi bangun", jawab dari rumah sambil bertanya siapa pula, "Siapa yang datang ini ?

Saya Mahruf dari batu sepuluh, jawab dari bawah itu.

Apakah khabar yang dibawa - naiklah ke rumah, Ruf. (Adapun si Mahruf ialah cbief mandur di dalam kebun bapa Aminah.) tanya Aminah.

"Di mana bapaku tak balik sampai sekarang, Abang Mahruf ?" kata

Jawab Mahruf, "Bntah. Saya datang disuruh Pak Jalil memberitahu ke rumah sini. Dianya bermalam di kebun sana [batu sepuluh] kerana kebun yang hendak awal besok pagi pergi ke batu delapan memeriksa bermalam di sana".

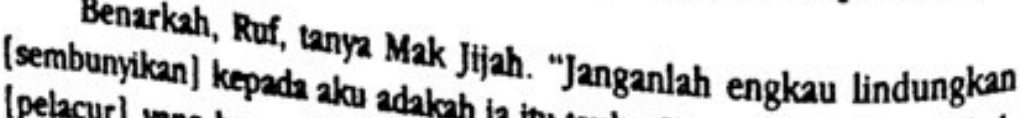
[pelacur] yang bermaku adakah ia itu tauke Cina atau tauke 'Neo'kah meleterkan apa-2pa yang ai sana? Dan terus sajalah mulut Mak Jijah Aku memang sangka ako ada terkasam di dalam hatinya. Katanya lagi,

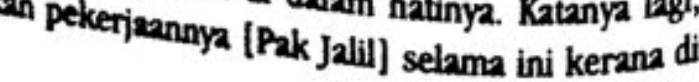


dalam bulan ini saja sudah tiga kali dia bermalam di sana. Padahal satu apa pun tiada yang perlu buat dijagai pada malam hari kerana cukup semua kerani mandur dan kuli yang ada di sana. ${ }^{54}$

\section{PENULARAN PENGARUH BARAT}

Rakawi Yusuf juga sensitif dengan penularan pengaruh Barat yang meresapi sikap dan pemikiran masyarakat Melayu zamannya. Tahun-tahun 1920-an menyaksikan pertumbuhan persatuan sosial dan hiburan yang agak pesat di Kuching. Rakawi Yusuf menganggapnya sebagai perkembangan yang tidak sihat jika dinilai dari perspektif Islam. Antaranya ialah Kampung Tanjung Kesenangan Club, Sarawak Malay Tennis Club, Sinjan Music Club dan Surabaya Jolly Minsterels. Ia berlaku terutamanya di kalangan masyarakat Melayu yang berpendidikan Barat. Namun, Rakawi Yusuf tidak pula menentang cara hidup Barat secara lantang dan keras. Rakawi Yusuf menerima kebaikan daripada pendidikan Barat dan menolak unsur negatifnya. Ia dapat dikesani melalui watak dan perwatakan Harun, keluarganya dan Yasin. Pengaruh budaya Barat jelas terpapar melalui dialog Harun dan Yassin. Rumah Harun dihiasi dengan perabot dari Barat. Tenis yang diminati oleh Harun dan Yasin juga memaparkan pengaruh sukan Barat. Kesemuanya ini mengalir dalam kehidupan mereka. ${ }^{55}$ Sebagai satu penonjolan yang jelas, Rakawi Yusuf menjadikannya sebagai latar tempat dalam bab pertamanya. Walaupun kehidupan mereka dipengaruhi unsur budaya Barat, tetapi Rakawi Yusuf menolak pandangan serong masyarakat terhadap pendidikan Barat. Harun dan keluarganya tetap berpegang teguh kepada Islam dan mementingkan pendidikan Islam. Begitu juga Yasin. Rakawi Yusuf tetap berpegang kepada ajaran Islam meskipun berpendidikan Barat. Rakawi Yusuf tidak khuatir dengan pendidikan Barat dan pengaruh budaya Barat yang mempengaruhi kehidupan golongan terpelajar Melayu, dengan syarat mereka menjadikan Islam sebagai asas kehidupan. Oleh itu, Rakawi Yusuf menempatkan pemikiran Islamnya di tempat yang sewajarnya. Beliau tidak mengenepikan Islam dalam hidupnya.

\section{SIKAP PBMUDA}

Rakawi Yusuf menegur sikap pemuda Melayu yang semakin liar akibat pengaruh 'gejala baru'. Antara fesyen 'zaman baru' yang popular di kalangan pemuda ialah 'bergondol kepala'.56 I2 turut mempengaruhi Harun dan Yasin. Pemudapemuda Melayu digambarkan suka 'bersiar-siar dan melimpas ke hulu ke hilir 
JURNAL SEJARAH

riuh rendah bunyi tempik dan sorak daripada hon-hon dan enjin-enjin motormotor itu' hingga menyebabkan 'naik kepeningan rasa kepala'. Keadaan ini digambarkan oleh Rakawi Yusuf ketika 'motorkar-motorkar dan motorsikal berduyun-duyun melimpas di Datus Road ketika senjakala di hari enam (Sabtu)' ${ }^{57}$ Ia mengganggu keharmonian penduduk di sekitar Datus Road. Rasa hormat sesetengah pemuda terhadap kepentingan orang lain, kian luntur. Namun, masih terdapat anak-anak Melayu yang taat dan hormat kepada ibu bapa seperti Harun, Yasin dan Nahariah. Mereka mewakili anak-anak Melayu yang masih menjaga maruah dan harga diri. Atas sifat ini, Harun dan Yasin segera balik ke rumah setelah mengorat Aminah di perkarangan rumahnya kerana bimbang 'kalau-kalau sumbang di mata orang' dan 'takut lekas jadi kurang ajar'. ${ }^{88}$

\section{PEMUDI BERHIAS}

Rakawi Yusuf mengkritik secara halus pemudi yang berhias secara keterlaluan. la bertujuan menggoda pemuda dan menunjuk-nunjuk kecantikan diri. Beliau tidak membantah pemudi berhias. Rakawi Yusuf mahu pemudi bersikap sederhana. Ia dinukilkannya melalui watak Aminah. Aminah seorang gadis yang cantik. Tetapi, dia meletakkan kecantikannya di tempat yang bercanggah dengan Islam. Islam menegah perempuan berhias kecuali untuk suaminya. Ia dibataskan pula di rumahnya sahaja. Namun, perbuatan Aminah menghias diri sematamata untuk mempamerkan kecantikannya, boleh menimbulkan fitnah. Ia juga mendekatkan pemuda-pemudi ke arah perzinaan. Rakawi Yusuf mengambarkan sikap keterlaluan Aminah dengan berkata :

Maka di antara jambangan-jambangan bunga itu terserlah seorang gadis yang rendah-remunai parasnya, putih kuning kulitnya dan lemah-lembut gerak anggotanya. Bertapih batik, perkalungan warna jingga bunga akar melilit, berbaju biru tua potongan bandung, bergelang kaki emas suasa dan bertudung kain lepas sutera warna kalas muda. . . Amboi ! Pada waktu itu jika siapa-siapa jua yang ada melimpas di jalan raya sesungguhnya lailatulkadarlah yang dijumpainya, ialah kerana hujan bedak dan inci
(gincu). 99 


\section{SIKAP NEGATIF}

Rakawi Yusuf juga memancarkan kritikan dan pemikirannya melalui Pak Jalil. Pak Jalil yang dilukiskan sebagai bapa yang tidak menghiraukan masalah keruntuhan akhlak pemuda-pemudi pada awalnya, akhirnya menginsafi kesilapannya. Rakawi Yusuf mahu pembaca mencontohi keinsafan Pak Jalil. Menerusi keinsafan Pak Jalil, Rakawi Yusuf melontarkan kritikan tajamnya terhadap sikap masyarakat Melayu yang memundurkan bangsanya. Rakawi Yusuf sedar ia sudah berakar-umbi dalam kehidupan mereka. Tetapi, ia dapat diperbaiki dengan menghisabkan diri dan menginsafi kelemahan bangsa. Bagi Rakawi Yusuf, perubahan itu mesti bermula dari diri sendiri. Ia merupakan titik-bengit perubahan bangsanya ke arah kemajuan. Kritikan Rakawi Yusuf terhadap sikap negatif masyarakatnya yang tidak menyumbang kepada kemajuan bangsa, dinyatakannya menerusi peringatan Pak Jalil kepada Mak Jijah :

[A]dapun manusia itu bukannya sama fikiran dan kesukaannya, ada yang suka memimpin orang ke jalan yang sebenar ada yang suka memimpin ke jalan sesat oleh kerana hasad dan dengki seorang kepada yang lain dan lagi aku tiada kuasa hendak menurut hawa nafsu orangorang kita di kampung ini yang sentiasa berlawan-lawan dan bertinggitinggi dalam hal bersuka ria kerana menghendaki puji biarpun di belakang kelak mereka menghitung kasur rumah asal saja mendapat puji to $^{00}$

\section{KEPERCAYAAN KARUT}

Kepercayaan kolot yang mendarahdagingi kehidupan masyarakat Melayu juga dikritik oleh Rakawi Yusuf. Beliau menyifatkannya sebagai penghalang kemajuan bangsanya. Bagi Rakawi Yusuf, pemikiran sedemikian tidak searus dengan zaman kemajuan. Ketika itu, masyarakatnya juga lebih mempercayai pawang, dukun dan bomoh daripada doktor. ${ }^{61}$ Rakawi Yusuf tidak melihat dunia perubatan tradisional akan mengangkat bangsanya ke arah kemajuan. Tetapi, Rakawi Yusuf percaya masyarakatnya harus beranjak kepada dunia perubatan moden dan menceburi bidang profesional. Ia dinyatakan oleh Rakawi Yusuf menerusi peristiwa kecederaan dahi Harun akibat terjatuh dari katil ketika mimpi 'berasmara' dengan Aminah. Bagi menutup malu, Harun membohongi ibu bapanya. Dia menyatakan kononnya 'didatangi oleh seorang hebat dan jahat 
rupa badannya berbulu seperti binatang mawas ( mayas ) berkuku panjang lagi kotor rupanya'. Harun kononnya cuba mengusirnya. Akibat sentakannya, Harun terpelanting dari katil. Bagi menyampaikan kritikannya terhadap kepercayaan karut dalam masyarakatnya, ia diungkapkan oleh Rakawi Yusuf menerusi dia. log ibu dan ayah Harun. Susulan daripada peristiwa tersebut, Mak Nafsiah berkata

Nah inilah dia bapa Harun! kata Mak Nafsiah, dari dulu sudah saya kata kepada abang tanah ini ada penunggunya kerana sudah ditilik oleh orang bermata empat (orang dukun yang bersahabat dengan hantu jembalang) siapa yang menyuruh memberi makan penunggu tanah ini dengan darah ayam hitam selasih waktu sebelum mendirikan rumah tetapi abang sangat bantahan dan tiada yakin kepada itu. Entah dia puaka itu yang telah menyakiti anak kita. ${ }^{62}$

Pak Noraldin membidas seraya berkata :

Hiss! kata Pak Noraldin, Jangan didatangkan perkara yang karut itu kepada telingaku...bawa lekas air panas, Nahariah ! Dan cucikan darah abangmu. Kemudian tutupkan dengan kapas sementara nanti doktor sampai ke mari...sebarang apa penyakit yang didapatinya hendaklah diubati oleh doktor-doktor yang ada qualification. ${ }^{63}$

\section{GOLONGAN TERPELAJAR MELAYU}

Berhubung kemunduran bangsanya, Rakawi Yusuf turut menyindir secara halus sikap segelintir golongan terpelajar Melayu yang tidak berminat memikirkan masalah dan masa depan bangsanya. Pada peringkat awalnya, watak ini diwakili memikirkan kepentingan dan nasib pemuda berpendidikan Barat yang enggan daripada membincangkan 'perbahasangsanya. Yasin cuba mengelakkan diri mutu anak-anak Melayu'bs dan 'tan yang panjang di dalam hal pelajaran dan bersembangtentang gendang Melayu. Tetapi, berwanga'. ${ }^{65}$ Yasin lebih berminat oleh Rakawi Yusuf sebaliknya. Walatapi, perwatakan Harun pula digambarkan letaknya kontradiksi perwatakan merek, Harun dan Yasin sepupu, di sinilah terpercik melalui pemikiran Rakawi meka. Inilah realiti masyarakat Melayu yang gendang Melayu terhadap akhlak pemuf. Namun, Yasin juga menyedari bahaya 
menyenangi sikap perempuan gendang yang menyalahgunakan pantun ketika bergendang. Tetapi, Harun yang lebih keras menentangnya. Pemikiran Rakawi Yusuf lebih banyak dipancarkan melalui Harun berbanding Yasin.

\section{KELEMAHAN EKONOMI}

Rakawi Yusuf juga melahirkan kekesalannya terhadap bangsanya yang ketinggalan dalam aspek ekonomi. Bukan sahaja di Kuching, malah di Sibu, bangsa asing terus menguasai ekonomi negeri terutamanya dalam aspek perniagaan di bandar. Mereka terdiri daripada peniaga Cina dan India. Rakawi Yusuf berusaha menyedarkan bangsanya daripada lalai dan leka dengan keseronokan sematamata. Akhlak pemuda-pemudi pula semakin rosak dan tercemar. Taraf dan kesedaran pendidikan mereka masih rendah. Kemunduran dan kerosakan bangsanya juga dikaitkan dengan permainan gendang Melayu. Pemuda-pemudi yang diharapkan memajukan bangsa dan nusa, terbelenggu dengan adat dan cara hidup yang tidak berfaedah. Malah, ia merendahkan mutu bangsanya. Rakawi Yusuf tidak menyalahkan kelemahan bangsanya semata-mata. Baginya, masyarakat Melayu juga ketinggalan dalam persaingan ekonomi kerana ketamakan bangsa asing. Mereka bertindak menyekat peniaga Melayu memajukan perniagaan mereka. Bangsa asing memonopolikan kekayaan ekonomi negeri dengan menafikan peluang perniagaan anak negeri. Rakawi Yusuf menyatakannya melalui peristiwa di Sibu. Hasrat ayah Harun, Pak Noraldin untuk membuka cawangan perniagaannya di Sibu tersekat. Menurut Harun, mereka 'sudah terlambat [kerana] semua pekerjaan di situ [ Sibu ] di dalam genggaman kompeni-kompeni kontraktor yang besar-besar iaitu Syarikat Gammon Malaya dan Sia An Company'. ${ }^{66}$ Oleh itu, Rakawi Yusuf melihat kemunduran bangsanya dalam aspek ekonomi dari dua dimensi iaitu dalam dan luaran. Kelemahan masyarakatnya tidak beliau nafikan. Pada masa yang sama, kesan ketamakan dan kekangan bangsa asing dilihat oleh Rakawi Yusuf sebagai puncanya juga. Walaupun Rakawi Yusuf sekadar menyenggol punca yang menyebabkan kelemahan bangsanya dalam aspek ekonomi, tanpa mengenepikan terdapatnya orang Melayu yang berjaya seperti Pak Jalil dan Pak Noraldin, tetapi beliau tidak pula mengemukakan saranannya untuk memajukan ekonomi masyarakatnya. Di sinilah letaknya kelemahan pemikiran Rakawi Yusuf dalam Melati Sarawak. Perkara ini mungkin tidak disedarinya. Lagipun, Melati Sarawak lebih menumpukan kepada persoalan gendang Melayu. Ini menyebabkan aspek tersebut agak terabai. 
JURNAL SEJARAH

112

Secara keseluruhannya, Rakawi Yusuf meletakkan aspirasi novelnya dalam dua cabang. Pertama, cita-cita untuk menyedar dan memacu bangsanya ke arah kemajuan dan mengeluarkan mereka daripada kemunduran. Kedua, memperbaiki kepincangan masyarakatnya yang merangkumi keseluruhan cara hidup mereka yang bercanggah dengan cita-cita kemajuan. Kedua-duanya bersifat komplementari. Menerusi Melati Sarawak, Rakawi Yusuf berpendapat kerosakan akhlak pemuda dan pemudi Melayu sebagai punca utama yang menyebabkan kemunduran bangsanya. Ia berpunca daripada permainan gendang Melayu khususnya selain sikap dan budaya yang merugikan bangsa. Ia menyebabkan pemuda-pemudi lalai dan leka dengan keseronokan semata-mata. Mereka lalai daripada memikirkan dan berusaha mengejar arus kemajuan. Mereka tidak sedar kelemahan dan kemunduran bangsanya yang jauh ketinggalan berbanding bangsa asing. Di sinilah letak duduknya tunjang tema Melati Sarawak. Keduadua bentuk aspirasi ini mempunyai keistimewaannya tersendiri. Aspirasi majornya disisipkan oleh Rakawi Yusuf secara tersirat. Tetapi, aspirasi minor didedahkannya kepada umum. Oleh itu, jika Melati Sarawak dibaca secara mendatar, aspirasi makronya tidak akan dapat dikesani. Hanya dengan memahami pemikiran dan latar belakang Rakawi Yusuf secara menyeluruh, barulah kita dapat mencungkil aspirasi majornya. Ia diselitkan oleh Rakawi Yusuf secara tersirat di sebalik yang tersurat. Daripada perbincangan ini, dua rumusan dapat dibuat. Pertama, kritikan Rakawi Yusuf terhadap gendang Melayu merupakan akar pemikirannya. Kedua, kritikannya terhadap aspek lain dijadikan sebagai rantingnya.

\section{KESIMPULAN}

Rakawi Yusuf, atas statusnya sebagai anak jati Sarawak, merupakan tokoh novelis pertama di Borneo yang menyahut cabaran dan rempuhan perkembangan pesat novel di Tanah Melayu pada awal 1930-an. Walaupun Melati Sarawak sememangnya ketinggalan dari segi tekniknya berbanding novel kontemporari, tetapi pemikiran Rakawi Yusuf masih sesuai sebagai renungan generasi masa kini. Rakawi Yusuf adalah nasionalis dan novelis Melayu Sarawak yang unggul sebelum Perang Dunia II. Beliau juga merupakan intelektual zamannya. Sehingga kini, belum ada penulis Sarawak yang dapat menandingi Rakawi Yusuf dari segi keberanian dan ketajaman pemikirannya. Jika ditinjau semula tema novel Melayu di Tanah Melayu dalam tempol"
1925-1941, ia menjuruskan kepada dua aspek utama iaitu sosial dan politik" 
Tetapi, Melati Sarawak tidak mengandungi tema politik. Melati Sarawak juga tidak memancarkan obor nasionalismenya seperti Putera Gunung Taban, hasil karya Ishak Haji Muhammad. Rakawi Yusuf tidak menggangap Brooke sebagai punca utama kemunduran bangsanya. Tetapi, Rakawi Yusuf tidak menafikannya secara total. Beliau melihatnya berpunca daripada kelemahan masyarakatnya sendiri iaitu faktor dalaman. Ini menyebabkan beliau menjadikannya sebagai paksi kritikannya dalam Melati Sarawak.

Rakawi Yusuf mengkritik kelemahan bangsanya secara jujur, lantang dan berani. Beliau tidak gentar dengan tohmahan, ancaman dan pemulauan masyarakatnya. Pemikirannya dipancarkan secara kritis. Beliau berhujah dengan jelas dan mantap apabila mengkritik kelemahan masyarakatnya. Rakawi Yusuf bukanlah seorang novelis yang provokatif semata-mata. Beliau turut mengemukakan saranan dan cadangan membina untuk mengatasi kelemahan bangsanya. Apabila berhadapan dengan 'gejala baru' akibat perubahan persekitarannya, masyarakatnya bersikap pasif dan reaktif. Mereka mudah terikutikut dengan perubahan semasa yang tidak memajukan bangsa. Tetapi, Rakawi Yusuf, sebagai golongan terpelajar yang sealiran dengan golongan reformis Islam di Tanah Melayu dan Indonesia, mengambil sikap proaktif. Beliau mengamati kesan baik dan buruk akibat pemasaran 'gejala baru' dalam kehidupan masyarakatnya. Ini menjadikan Rakawi Yusuf seorang pemikir yang radikal dalam konteks zamannya.

Rakawi Yusuf tidak menolak kesemua pengaruh Barat dan kemodenan. Beliau bersikap selektif. Sikap selektifnya juga terbukti melalui kritikannya terhadap adat dan budaya lapuk yang memundurkan bangsanya. Oleh itu, Rakawi Yusuf bersikap kritis dan selektif terhadap unsur luaran dan dalaman, disamping bersikap protektif terhadapnya. Rakawi Yusuf mahu masyarakatnya membebaskan diri daripada segala macam kongkongan dan norma hidup tradisional yang bertentangan dengan pemikiran kemajuan. Beliau menggesa masyarakatnya menyesuaikan diri dengan arus pembaharuan dan kemajuan.

Rakawi Yusuf berharap masyarakatnya berubah ke arah kemajuan. Tetapi, beliau tidak menggunakan pendekatan drastik. Rakawi Yusuf memperbaiki kelemahan dan kerosakan bangsanya secara beransur-ansur. Kaedah yang digunakannya ialah melalui proses pendidikan Islam dan kegiatan berpersatuan. Rakawi Yusuf tidak pula menyarankan penggunaan kuasa dan undang-undang khususnya, bagi menyekat atau menghapuskan adat dan budaya yang dianggapnya memundurkan dan merosakkan masyarakatmya. Mungkin, Rakawi Yusuf tidak 
terfikir ke arah itu. Atau, mungkin beliau amat yakin dengan pendekatannya yang halus dan secara beransur-ansur.

Bagi golongan terpelajar Melayu di Sarawak, kelahiran Melati Sarawak amat bermakna. Kegagalan Fajar Sarawak 1930, tidak mematahkan semangat memperjuangkan hak dan kepentingan bangsa. Kegagalan itu ada hikmahnya tersendiri. Ia menjadikan novel sebagai 'alat pengucapan cita-cita' mereka yang baru. Melati Sarawak jelas memperlihatkan nada pengajarannya secara tegas dan lantang. Ia tidak diolah dengan nada 'memberontak'. Melati Sarawak merupakan wadah bagi Rakawi Yusuf memuntahkan protesnya dan menghembuskan kesedaran terhadap masalah yang menimpa bangsanya. Ia bertitik-tolak daripada masalah keruntuhan akhlak yang berpunca daripada gendang Melayu, sehingalah membawa kepada kemunduran bangsanya. Justeru, Melati Sarawak merupakan dokumentasi pergolakan dan pertentangan dalam masyarakatnya, yang paling hidup dan murni untuk melihat kebenaran realiti kehidupan masyarakat Melayu zamannya.

Rakawi Yusuf gemar menimbulkan suspen yang sia-sia dan membosankan dengan cara merahsiakan nama seseorang watak tetapi terus menghuraikan lakonan dan keadaan sekitarnya. Bahasa yang digunakannya kadang-kadang sukar difahami. Novelnya dipengaruhi tatabahasa dan istilah Inggeris dan Arab. Melati Sarawak juga sarat dengan istilah bahasa Melayu Sarawak. Bagi pembaca yang tidak memahaminya, ini menyukarkan dan membosankan. Rakawi Yusuf juga menggunakan ayat yang panjang berjela. Tetapi, ayat dialognya pula diolah dengan padat dan pendek. Ia mengesani jiwa pembaca. Di sinilah letaknya keistimewaan Melati Sarawak di sebalik kelemahannya. Malah, jika ditinjau keseluruhan gaya bahasa novel Melayu di Tanah Melayu sebelum Perang Dunia II, ia juga tidak banyak berbeza dengan Melati Sarawak. ${ }^{68}$ Ia kelihatan seperti unsur yang 'universal' bagi novelis Melayu sezaman.

Rakawi Yusuf menggambarkan masyarakat Melayu sebagai sebuah masyarakat yang mempunyai buruk dan baiknya. ${ }^{69}$ Keruntuhan akhlak masyarakatnya tidaklah terlalu teruk tetapi tidak juga boleh dipandang ringan ${ }^{*}$ Malah, Rakawi Yusuf mendapati keruntuhan akhlak di Singapura lebih teruk
berbanding di Kuching. Jika Melati Sarawak dinilai sebagaing
mengadakan perubahan mengadakan perubahan dalam marawak dinilai sebagai karya yang bertujuan oleh pengarangnya ialah gendang perempuan, jelas perkara utama yang dikritik perempuan menerangkan dengan jempuan. Pendapatnya mengenai gendang zamannya. Rakawi Yusuf menyedan jelas pandangan Rakawi Yusuf mengenai masyarakatnya sedang berubah dan 
amalan yang paling tradisi sekalipun haruslah dinilai semula, malah dihapuskan. Dunia Rakawi Yusuf kaya dengan pelbagai pandangan dan pendapat, dan penyelesaiannya terhadap masalah yang sukar, ${ }^{71}$ dikemukakannya dari pelbagai dimensi.

Rakawi Yusuf tidak terikat oleh sesuatu prasangka dan menganggap semua amalan Barat, di kota dan di seberang laut sebagai pembawa kerosakan. Beliau mampu mengemukakan pelbagai penilaian dan menyarankan berbagai-bagai penyelesaian walaupun tidak kesemuanya benar-benar memuaskan. Pandangan Rakawi Yusuf jauh berbeza daripada penulis sezaman dengannya yang melihat hanya ada satu penyelesaian yang mudah terhadap kelemahan semasa masyarakat. ${ }^{72}$ Ia mungkin disebabkan pengalaman masyarakat dan persekitaran silam serta semasa yang agak berbeza antara Rakawi Yusuf di Bumi Kenyalang, dengan rakan seperjuangannya di Tanah Melayu.

Melati Sarawak adalah sebuah novel tahun 1930-an yang patut dipuji. ${ }^{73}$ Novel ini agak terbuka dan bebas mengemukakan tafsiran mengenai masalah masyarakat di Kuching. ${ }^{74}$ Rakawi Yusuf mencipta watak yang dapat mengakui bahawa penyelesaian terhadap masalah itu ( gendang Melayu ) memang sukar. ${ }^{75}$ Melalui Melati Sarawak, Rakawi Yusuf berjaya mengungkapkan kerencaman masalah dan masa depan bangsanya dengan kritis dan mudah difahami. Novelnya membicarakan aspek yang agak sensitif dalam masyarakat zamannya. Ia menunjukkan kesensitifan pemikiran dan ketajaman pemikiran Rakawi Yusuf terhadap adat dan budaya yang menghambat kemajuan bangsanya. Rakawi Yusuf berjaya menghasilkan sebuah novel, yang kalaulah tidak kerana halangan atau suratan waktu, mungkin menjadi contoh cereka Borneo yang ulung." 


\section{NOTA}

* Artikel ini diabadikan sempena persaraan Profesor Madya Dr. Adnan Haji Nawang ( Pak Nan), Ketua Jabatan Sejarah 1999/2000 dan penyelia tesis sarjana penulis. Tidak lupa juga buat srikandi tersayang, Nurul Natsya Nabilah yang dilahirkan pada 26 Jun 2000.

1 Untuk perbincangan lanjut tentang sejarah perkembangan novel sebelum Perang Dunia II, rujuk Safian Hussain (et. al. ), Sejarab Kesusasteraan Melayu, Dewan Bahasa dan Pustaka, Kuala Lumpur, 1981, hlm. 109-152.

Untuk senarai lengkapnya, rujuk Hashim Awang, Novel-Hikayat, Tesis Ph. D., Jabatan Pengajian Melayu, Universiti Malaya, 1986, hlm. 359-377.

Dalam artikel ini, penulis hanya menggunakan 'Rakawi Yusuf sahaja, beliau lebih dikenali dengan nama tersebut.

Perbincangan tentang peranan dan kepentingan tokoh tersebut lebih banyak diperkatakan berbanding Rakawi Yusuf. Antaranya, ( sekadar menyebut beberapa contoh ) rujuk, Mohd. Yusof Hasan, Pengbayatan Fiksyen Melayu, Dewan Bahasa dan Pustaka, Kuala Lumpur, 1995. Hamzah Hamdani, NovelNovel Malaysia Dalam Kritikan, Dewan Bahasa dan Pustaka, Kuala Lumpur, 1993. Li Chuan Siu, Ikbtisar Sejarah Kesusasteraan Melayu Baru 1840. 1945, Pustaka Antara, Kuala Lumpur, 1966.

5 Jika dilihat perkembangan novel di Malaysia umumnya, penerbitan Melati Sarawak seangkatan dengan perkembangan awal novel Melayu di Tanah Melayu. Ia merupakan novel kelapan dihasilkan dan Rakawi Yusuf adalah novelis kelapan di Malaysia. Selepas Melati Sarawak, perkembangan kesusasteraan di Sarawak khususnya dan Borneo umumnya terbantut. Ia digiatkan semula pada akhir 1960-an. Saleh Abdul Latif yang menghasilkan novel Garis Cerab Di Ufuk Senja pada 1968. Novel Menunggu Esok, hasi karya Salbiah Painah diterbitkan pada 1970. Kedua-duanya diterbitkan di Kuching. K. Bali, nama pena bagi Abdul Rahim Abdullah yang berasal dari Kelantan dan menetap di Tanjung Aru, Sabah, menghasilkan novel yang bertajuk Sarini Bogel pada 1969. Terdapat juga penulis dari Semenanjung yang menggunakan Borneo sebagai latar tempat dalam novel seperti Harul Aminurashid dan S.H. Nattas. Dalam konteks inilah, sebuah novel dari Sarawak yang ditemui pada 1979, kembali dianggap penting dalam sejarah kesusaster2at Sarawak khususnya dan Malaysia umumnya. Muhammad Rakawi Yusuf, Melatio Sarawah, Dewan Bahasa dan Pustaka, Kuala Lumpur, 1987, hlm. xv-xvi. tinnuk perbincangan lanjut tentang perkembangan mutakhir cerpen di Sarawak, ruivt Sastera Bandingan Dari Perspektif Kita, Fakulti Sains Kemasyarakat des Kemanusizan, Universiti Kebangsaan Malaysia, Bangi, 1995, hlm. 41-55. 
mengenali asas kesusasteraan Melayu, rujuk Hashim Awang ( at. al.), Mendekati Kesusasteraan Melayu, Fajar Bakti, Petaling Jaya, Selangor, 1985.

6 Hamzah Hamdani menyatakan Rakawi Yusuf pernah mendapat pendidikan di Madrasah Melayu Sarawak. Ia tidak tepat dan mengelirukan. Madrasah Melayu Sarawak ditubuhkan pada 1931. Ia adalah hasil gabungan antara Kolej Kebangsaan Sarawak, yang ditubuhkan pada 1904, dengan Sekolah Kampung Jawa, yang diasaskan pada 1883. Oleh itu, tidak logik menyatakan Rakawi Yusuf pernah mendapat pendidikan di Madrasah Melayu Sarawak. Ketika itu, Rakawi Yusuf telah bersara sebagai pegawai kastam, menerbitkan Fajar Sarawak dan giat menulis Melati Sarawak dan Hikayat Sarawak. Beliau berusia dalam lingkungan akhir 30-an atau awal 40-an. Rujuk, Hamzah Hamdani, 'Melati Sarawak', dalam Dewan Sastera, Bilangan 14, 15 Jun 1984, hlm. 31. Untuk perbincangan lanjut tentang perkembangan pendidikan di Sarawak zaman Brooke, rujuk Sabihah Osman, Perkembangan Pelajaran Bumiputera Sarawak 1841-1941, Dewan Bahasa dan Pustaka, Kuala Lumpur, 1990.

7 Ibid.

8 Ibid.

9 Mohd. Rani Mohd. Setar, 'Kegiatan Penulisan Golongan Melayu Terpelajar Di Sarawak Dalam Bidang Penulisan 1930-1950', dalam Malaysia Dari Segi Sejarah, Jurnal Persatuan Sejarah Malaysia, Bil. 13, 1984, hlm. 64-65.

10 Nordi Achie, Akhbar Melayu Perjuangan Di Sarawak ; Satu Kajian Khusus Terhadap Fajar Sarawak 1930 dan Utusan Asas 1947-1948, Draf Tesis M.A., Jabatan Sejarah, Universiti Malaya, 1999/2000, hlm. 102.

11 Penulis mengenali gendang Melayu sejak awal 1980-an lagi. Ia diadakan di kampung hampir setiap kali majlis perkahwinan berlangsung. Pada awal 1990an, penulis pernah menjadi penandak nopeng. Selain bertandak nopeng di kampung, penulis pernah bertandak nopeng di Kampung Sejaie, Iboi dan Bukit Siol. Penulis hanya berhenti bertandak nopeng setelah menjejakkan kaki ke Universiti Malayz mulai 1993. Latar belakang ini ditulis berdasarkan pengalaman dan pemerhatian penulis.

12 Muhammad Rakawi Yusuf, Melati Sarmuah, hlm. 3.

13 Ibid., hlm. 44-45.

14 Ibid., hlm. 6.

15 Ibid., hlm. 49-50.

16 Ibid., hlm. 50.

17 Ibid., hlm. 10.

18 Ibid., hlm. 2.

19 Ibid., hlm. 7. 
20 Ibid., hlm. 5.

21 Ibid., hlm. 5.

22 Ibid., hlm. 19.

23 Ibid., hlm. 20.

24 Ibid., hlm. 37-38.

25 Ibid., hlm. 37-39.

26 Ibid., hlm. 39-40.

27 Ibid., hlm. 44.

28 Ibid., hlm. 43.

29 Ibid., hlm. 25.

30 Ibid., hlm. 26.

31 Ibid., hlm. 27.

32 Ibid., hlm. 26.

33 Ibid., hlm. 5.

34 Ibid., hlm. 36-37.

35 Ibid., hlm. 66.

36 Ibid., hlm. 59-61.

37 Ibid., hlm. 62.

38 Ibid., hlm. 63.

39 Ibid., hlm. 68.

40 Ibid., hlm. 67.

41 Ibid., hlm. 76-77.

42 Ibid., hlm. 80.

43 Berhubung latar belakang awal pendidikan anak-anak perempuan Melayu di Sarawak, rujuk, Sabihah Osman, Perkembangan Pelajaran Bumiputera

44 Muhammad Rakawi, hlm. 45-46 dan 61-62.

45 Ibid., hlm. 48.

46 Ibid., hlm. 25-26.

47 Ibid., hlm. 55.

48 Ibid., hlm. 16.

49 Ibid., hlm. 15.

50 Ibid., hlm. 18.

51 Untuk perbincangan lanjut tentang peranan dan kedudukan golongan Political Prouk Abang Yusuf Puteh, The Malays of Sarawak; $A$ Socio. 641.

Muhammad Rakawi Yusuf, Melati Sarawak, hlm. 4. 
53 Ibid., hlm. 15.

54 Ibid., hlm. 17.

55 Contohnya ialah perkataan cousin, sleeping suit, library, bello, settee, cigarate, land dispute, land inspector, surveyor, report, instructions, steam, pocket diary, ovaltine dan Good night for you.

56 Ibid., hlm. 13.

57 Ibid., hlm. 12.

58 Ibid., hlm. 14.

59 Ibid., hlm. 12.

60 Ibid., hlm. 63.

61 Ketika amat merindui Harun, Aminah menangis tersendu-sendu di dalam biliknya. Esakan tangisannya dan gegaran katilnya menyedarkan ibu bapanya dari tidur. Mak Jijah bergegas ke bilik Aminah dan memanggil dukun untuk mengubats Aminah yang disangkanya diserang penyakit sika. Mak Jijah juga masih mempercayai mimpi yang karut-marut. Dia mentafsirkan mimpi Aminah kononnya anaknya akan dipinang oleh orang ternama. Ia merujuk kepada buaya yang menerkam Aminah ketika mandi di pangkalan dalam mimpi 'faraj'nya. Ibid., hlm. 52-53.

62 Ibid., hlm. 47.

63 Ibid.

64 Ibid., hlm. 4.

65 Ibid., hlm. 8.

66 Ibid., hlm. 75-76.

67 Untuk perbindangan lanjut, rujuk Hashim Awang, 'Fiksyen Melayu Di Antara Tahun-Tahun 1925-1941 : Satu Tinjauan Sejarah Sosial Masyarakat Pribumi Sebelum Perang Dunia II', dalam Malaysia : Sejarab dan Proses Pembangunan, Persatuan Sejarah malaysia, Kuala Lumpur, 1982, hlm. 214 233.

68 Hamzah Hamdani, 'Melati Sarawak,' hlm. 37.

69 Muhammad Rakawi Yusuf, Melati Sarawak, hlm. vili.

70 Ibid., hlm. xii.

71 Ibid., hlm. viii.

72 Ibid., hlm. ix.

73 Ibid., hlm. xiv.

74 Ibid.

75 lbid.

76 Ibid. 